Tropical Journal of Pharmaceutical Research September 2020; 19 (9): 1879-1885

ISSN: $1596-5996$ (print); 1596-9827 (electronic)

(C) Pharmacotherapy Group, Faculty of Pharmacy, University of Benin, Benin City, 300001 Nigeria

Original Research Article

http://dx.doi.org/10.4314/tjpr.v19i9.12

\title{
Denatonium benzoate decreases the effect of histamine in vitro and in rats
}

\author{
Plamen I Zagorchev ${ }^{1,2}$, Vesela Yu Kokova ${ }^{3 *}$, Elisaveta G Apostolova ${ }^{3}$, Milena N \\ Draganova-Filipova ${ }^{2,4}$ \\ ${ }^{1}$ Department of Physics and Biophysics, Faculty of Pharmacy, ${ }^{2}$ Research Institute at Medical University-Plovdiv, ${ }^{3}$ Department of \\ Pharmacology and Drug Toxicology, Faculty of Pharmacy, ${ }^{4}$ Department of Medical Biology, Medical Faculty, Medical \\ University-Plovdiv 15A Vasil Aprilov Blvd, 4002 Plovdiv, Bulgaria
}

*For correspondence: Email: vesela_uk@abv.bg; Tel: +359 32602099

Sent for review: 10 June 2020

Revised accepted: 26 August 2020

\begin{abstract}
Purpose: To evaluate the effect of denatonium benzoate (DB) in histamine-induced model of inflammation and the effect of the selective $\mathrm{H1}$ receptor agonist (2-(2-Pyridyl) ethylamine) on rat gastric smooth muscle strips pretreated with $D B$.

Methods: The anti-inflammatory effect of $D B$ was evaluated in vivo on histamine-induced rat paw edema. In vitro studies on spontaneous muscle contraction were performed on smooth muscle strips isolated from rat gastric corpus.

Results: The results showed a well-defined anti-inflammatory effect of DB (15 mg/kg) during the early stage of rat paw edema at the 15th $(p<0.001)$, 30th $(p<0.01)$ and 60th min $(p<0.001)$ compared to control. In vitro experiments indicated reduced spontaneous contractile activity of smooth muscle strips to $\mathrm{H} 1$ receptor agonist in the presence of $D B(0.5 \mu \mathrm{M})$. The vascular effects of histamine are mediated by $\mathrm{H} 1$ receptors. Substances, which reduce the effect of histamine on the $\mathrm{H} 1$ receptors could influence the early stage of histamine-induced inflammation.

Conclusion: The results show that the anti-inflammatory activity of $D B$ probably is related to its antagonistic activity on histamine $\mathrm{H} 1$ receptors. The results would contribute to the search for new antiinflammatory drugs.
\end{abstract}

Keywords: Denatonium benzoate, Inflammation, Histamine, Muscle contraction

\begin{abstract}
This is an Open Access article that uses a fund-ing model which does not charge readers or their institutions for access and distributed under the terms of the Creative Commons Attribution License (http://creativecommons.org/licenses/by/4.0) and the Budapest Open Access Initiative (http://www.budapestopenaccessinitiative.org/read), which permit unrestricted use, distribution, and reproduction in any medium, provided the original work is properly credited.
\end{abstract}

Tropical Journal of Pharmaceutical Research is indexed by Science Citation Index (SciSearch), Scopus, International Pharmaceutical Abstract, Chemical Abstracts, Embase, Index Copernicus, EBSCO, African Index Medicus, JournalSeek, Journal Citation Reports/Science Edition, Directory of Open Access Journals (DOAJ), African Journal Online, Bioline International, Open-J-Gate and Pharmacy Abstracts

\section{INTRODUCTION}

Denatonium benzoate (DB) is a synthetic bitter compound used to activate bitter taste receptors (TAS2Rs) in different cell types. It is known as an agonist of eight subtypes of TAS2Rs - 4, 8, 10, $13,30,39,43$, and $46[1,2]$. The TAS2Rs are Gprotein receptors initially found on the tongue.
Recently, their location in other tissues has been revealed, which triggered intensive research in the field. TAS2Rs are detected on human airway smooth muscles, immune cells, in the gastrointestinal tract, and the human brain [2,3], suggesting that their activation could lead to their participation in different physiological functions. Many gene variants of TAS1R-TAS2R are 
related and correlate with the expression of genes associated with maintaining of the homeostasis. Its disturbance, caused by different stress inducers (diseases as diabetes, inflammatory or tumor processes), plays a role in premature human aging. A link has been found between the expression of some taste receptor genetic variants and longevity [4].

The number and subtypes of TAS2Rs vary widely across different species - humans have 25 TAS2Rs and rodents 35 TAS2Rs [5]. Furthermore, activation of TAS2Rs results in a different effect depending on the concentration of the bitter compound, the type of the tissue and the region of the tissue. For example, in smooth muscles, TAS2R agonists evoked concentrationdependent contractility changes in mouse gastric smooth muscles [6]. Regarding the skeletal muscles, our previous research showed that DB decreased the force of rat abdominal muscle contractions [7].

TAS2Rs are also expressed in human blood leukocytes $[8,9]$ and some researchers have described the anti-inflammatory properties of the TAS2R agonists [8]. DB reduces lipopolysaccharide-induced pro-inflammatory cytokine secretion by human lung macrophages [2].

The fact that the anti-inflammatory activity of DB and its molecular mechanisms are still not clear, indicates that there are not enough studies conducted on the effect of this agonist on the early phase of inflammation.

Histamine, a biogenic amine, is the main regulator of acute inflammation and hypersensitive allergic reaction. It is also involved in the regulation of important physiological processes such as cell proliferation and differentiation, hematopoiesis and tissue regeneration [10]. It is released from storage granules in mast cells as part of the allergic response to tissue damage and/or an antigen. The different effects of histamine are mediated by four types of histamine receptors $(\mathrm{H1}, \mathrm{H} 2, \mathrm{H} 3$, and $\mathrm{H} 4$ ) that belong to the superfamily of $\mathrm{G}$ protein coupled receptors [11].

As the main signal transducers, $G$ proteins transmit the extrinsic stimuli inside the cells. Histamine $\mathrm{H} 1$ receptor is expressed in different cell types, like neurons, endothelial cells, muscle cells, hepatocytes, chondrocytes, monocytes, neutrophils, eosinophils, DCs, T and B lymphocytes etc. [12]. Its activation is linked not only with pro-inflammatory gene expression but also with smooth muscle relaxation.
Based on a brief review of the literature it was hypothesized that DB influences on histamine $\mathrm{H} 1$ receptors. Therefore, the aim of the study was to evaluate the effect of DB on histamine-induced rat paw inflammation in vivo and to examine the effect of the selective $\mathrm{H} 1$ receptor agonist (2-(2Pyridyl) ethylamine) in vitro on rat gastric smooth muscle strips pretreated with DB.

\section{EXPERIMENTAL}

\section{Drugs and solutions}

Denatonium benzoate, histamine dihydrochloride, acetylcholine and 2-(2-Pyridyl) ethylamine were purchased from Sigma. Solution for injection of diclofenac sodium $\left(\right.$ Almiral ${ }^{\circledR}$ ) was purchased from a pharmacy store.

The composition of the preparation solution was as follows: $\mathrm{Na}^{+}$(143); $\mathrm{K}^{+}$(5.84) and $\mathrm{Ca}^{2+}(3.7$ $\mathrm{mmol} / \mathrm{L})$, while the composition of modified Krebs' solution (KS) was: $\mathrm{Na}^{+}-143 ; \mathrm{K}^{+}-5.84$; $\mathrm{Ca}^{2+}$ - 2.5; $\mathrm{Mg}^{2+}$ - 1.19; $\mathrm{Cl}^{-}-133 ; \mathrm{HCO}_{3}^{-}$- 16.7; $\mathrm{H}_{2} \mathrm{PO}_{4}{ }^{-}-1.2$ and glucose $-11.5 \mathrm{mmol} / \mathrm{L}$.

\section{Animals}

Male Wistar rats $(175-230 \mathrm{~g})$ were kept under standard laboratory conditions (temperature $22 \pm$ $1{ }^{\circ} \mathrm{C}$, humidity $45 \%$, 12-h dark/light cycle, food and water ad libitum).

Approvals from the Bulgarian Food Safety Agency (permit no. 252/22.11.2019) and Ethics Committee of the Medical University - Plovdiv, Bulgaria (protocol no. 1/13.02.2020) were obtained before the experiments. The study was conducted according to the International Council for Ethical Guidelines for Animal Breeding Labs for Researchers, ARRIVE, and the EU Directive 2010/63/EU for animal experiments [13,14].

\section{In vivo evaluation of the effect of $D B$ in histamine-induced inflammation}

Twenty-four male Wistar rats $(175-230 \mathrm{~g})$ were divided into four groups $(n=6)$ and treated intraperitoneally as follows: 1-st group (controls) - treated with saline $(0.1 \mathrm{ml} / 100 \mathrm{~g}$ bw), 2-nd group - treated with diclofenac in a dose of 25 $\mathrm{mg} / \mathrm{kg}$ bw, 3-rd group - treated with DB $10 \mathrm{mg} / \mathrm{kg}$ bw (dissolved in saline), and 4-th group - treated with DB $15 \mathrm{mg} / \mathrm{kg}$ bw. The volume of each injection was $100 \mu \mathrm{L} / 100 \mathrm{~g}$ bw. One hour after the treatment, the animals received subplantar injection of $100 \mu \mathrm{L}$ of a $0.1 \%$ solution of histamine in saline into the right paw [15]. Before the injection of histamine and $5,15,30,60,90$ and $120 \mathrm{~min}$ after the treatment the anti- 
inflammatory effect was studied using Plethysmometer (UgoBasile, Gemonio, Italy) as described previously [16].

Change in paw -volume $(P)$ was calculated as in Eq 1.

$P(\%)=\left\{\left(V_{n}-V_{0}\right) / V_{0}\right\} 100$

where $\mathrm{P}(\%)=$ increase in paw volume, $\mathrm{Vn}=$ the volume of the right hind paw registered after histamine injection at the $\mathrm{n}$-th minute; and $\mathrm{V}_{0}=$ the volume of the right hind paw registered for the same animal before histamine injection.

In vitro study on the effect of DB on rat smooth muscle contractility

\section{Isolation of smooth muscle strips}

Male Wistar rats weighing 175 - $230 \mathrm{~g}$ were euthanized and the smooth muscle preparations without mucosa were isolated. Preparations were obtained while cutting the muscle tissue into strips $(20.0 \pm 1.5 \mathrm{~mm}$ length, $3.0 \pm 0.5 \mathrm{~mm}$ width). The samples were immediately rinsed in cooled $\left(4{ }^{\circ} \mathrm{C}\right)$ preparation solution. They were randomly allocated and isometrically fixed in individual organ baths prefilled with $15 \mathrm{~mL}$ modified Krebs' solution (KS) with temperature $35.5 \pm 0.25^{\circ} \mathrm{C}$.

The isolated strips were connected to an isometric force transducer (TRI 201, LSi LETICA; Pnlab S.L., Barcelona, Spain) and constantly oxygenated with $95 \% \mathrm{O}_{2}$ and $5 \% \mathrm{CO}_{2}$. Tension of $7 \mathrm{mN}$ was applied to achieve isometrical recording. The muscle strips were allowed an equilibration period of $20 \mathrm{~min}$ before the recording of contractile activity [17].

\section{Concentration-response curve for $D B$}

The normal contractile activity was recorded after the equilibration period. Baseline tone (BT), frequency, mean amplitude (Amean) and area under the curve (AUC) were analyzed. The concentration-effect curve was obtained based on experiments on the following concentrations of DB: $0.03,0.1,0.3,0.5,1,3,7,10,30$ and 60 $\mu \mathrm{M}$. DB was added to the organ baths and the change in the spontaneous contractile activity was recorded for a 5-min period. The strips were washed out with KS before adding a higher concentration. The cut-off time for each experiment was 45 minutes after muscle isolation.
Effect of 2-(2-Pyridyl) ethylamine on spontaneous smooth muscle contraction of strips before and after treatment with $D B$

The normal contractile activity was recorded as described previously [18]. Briefly, BT, frequency, Amean and AUC were analyzed for a 5-min period (baseline period). The data was used for further comparative analysis.

2-(2-Pyridyl) ethylamine $(1 \mu \mathrm{M})$ was added to the organ baths and changes in spontaneous activity were recorded for $5 \mathrm{~min}$. The strips were washed out with $\mathrm{KS}$ and $0.5 \mu \mathrm{M} \mathrm{DB}$ was added to the organ baths. After $30 \mathrm{~min}$, in the presence of DB, $1 \mu \mathrm{M} 2$ 2-(2-Pyridyl) ethylamine was added to the organ baths. The aforementioned parameters (BT, frequency, Amean and AUC) were analyzed again for a 5-min period.

For each test, seven preparations from different animals were used. Each parameter was presented as a relative increment corresponding to the baseline period data.

\section{Statistics}

Statistical analysis was performed using SPSS 17.0. The normal distribution was evaluated with One-sample Kolmogorov-Smirnov test. In case of normal distribution, One-way ANOVA and Bonferroni post hoc test were employed for further analysis. Data, which did not show normal distribution, were analyzed using non-parametric Wilcoxon signed rank test.

The results of in vivo experiments are reported as mean \pm SEM, and those of in vitro evaluations are presented as mean, 25 and $75 \%$ percentiles. The number of tested preparations is given as $n$. Results were considered significant at $p<0.05$.

\section{RESULTS}

\section{Effect of DB on histamine-induced rat paw edema}

The results showed a reduction in paw volume at the 15-th minute after histamine injection in the group treated with lower dose of DB $(10 \mathrm{mg} / \mathrm{kg})$ when compared to rats treated with diclofenac $(31.5 \pm 2.9$ vs $53.5 \pm 4.1 \% ; p<0.05)$, as shown in Figure 1.

The paw volume of rats treated with higher dose DB (15 mg/kg bw) was significantly lower than control rats $(11.9 \pm 6.3$ vs $51.9 \pm 6.1 \% ; p<$ $0.001)$ and rats, treated with diclofenac (11.9 \pm 6.3 vs $53.5 \pm 4.1 \% ; p<0.001)$. 


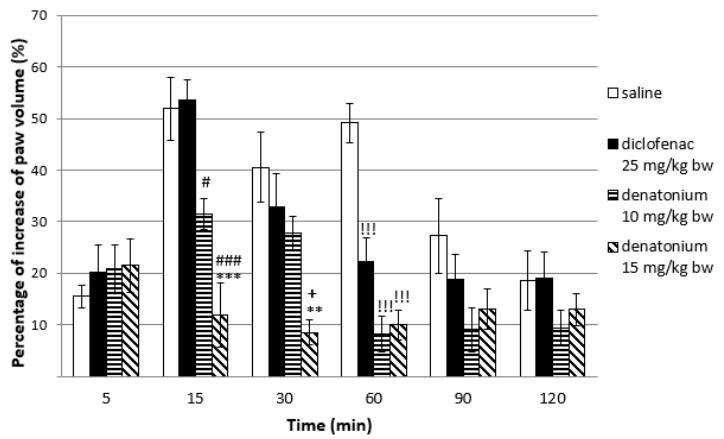

Figure 1: Anti-inflammatory effect of denatonium benzoate in histamine-induced paw edema after single administration. ${ }^{* * *} p<0.001$ compared to saline at 15 $\mathrm{min} ; \# p<0.05$ compared to diclofenac at $15 \mathrm{~min}$; \#\#p $<0.001$ compared to diclofenac at $15 \mathrm{~min} ;{ }^{* *} p<0.01$ compared to saline at $30 \mathrm{~min} ;+p<0.05$ compared to diclofenac at $30 \mathrm{~min} ; ! ! ! p<0.001$ compared to saline at $60 \mathrm{~min}$

The results showed a well-defined antiinflammatory effect of DB in a dose of $15 \mathrm{mg} / \mathrm{kg}$ that persisted at the 30 minute after histamine application when a significant decrease was observed in comparison to the groups treated with saline $(8.5 \pm 2.3$ vs $40.5 \pm 6.8 \% ; p<0.01)$ and diclofenac $(8.5 \pm 2.3$ vs $32.9 \pm 6.4 \% ; p<$ $0.05)$. One hour after the histamine injection, all tested substances showed eminent antiphlogistic effect. Comparing the paw volume change, a significant decrease was detected in the groups treated with diclofenac $(22.2 \pm 4.8$ vs $49.2 \pm 3.8$ $\% ; p<0.001)$, DB $10 \mathrm{mg} / \mathrm{kg}(8.2 \pm 3.5$ vs $49.2 \pm$ $3.8 \% ; p<0.001)$, and DB $15 \mathrm{mg} / \mathrm{kg}(10.0 \pm 2.9$ vs $49.2 \pm 3.8 \% ; p<0.001)$ in comparison to controls.

\section{Concentration-response denatonium benzoate (DB)}

curve

Figure 2 represents the concentration-response curve for DB. The maximal muscle contraction induced by the addition of $10 \mu \mathrm{M}$ acetylcholine to the organ baths was taken as $100 \%$.

Figure 3 shows the effect of $0.5 \mu \mathrm{M}$ DB on the spontaneous contractility of smooth muscle strips isolated from rat gastric corpus.

\section{In vitro effect of DB on spontaneous smooth muscle contraction of strips treated with $\mathrm{H} 1$ agonist}

When added to organ baths containing solely KS, 2-(2-Pyridyl) ethylamine evoked a statistically significant increase in AUC, the amplitude, and BT. These parameters underwent changes when DB was present in the organ baths, as shown in Fig.4. The mean AUC was reduced from $1.92(1.79-1.96)$ to $1.42(1.38-$ $1.48)$ before and after addition of $0.5 \mu \mathrm{M} \mathrm{DB}(p<$ $0.05 ; n=7)$. The Amean of the contraction was also diminished $(1.82(1.77-1,88)$ vs $1.39(1.35$ $-1.44) ; p<0.05 ; n=7)$, respectively. The BT also declined when 2-(2-Pyridyl) ethylamine was added to organ baths, containing $\mathrm{KS}$ and $0.5 \mu \mathrm{M}$ DB $(1.53(1.42-1.64)$ in comparison to KS $(1.97$ (1.95 - 1.99); $p<0.05 ; n=7$; Wilcoxon signed rank test). No change on the phasic contraction frequency was observed.

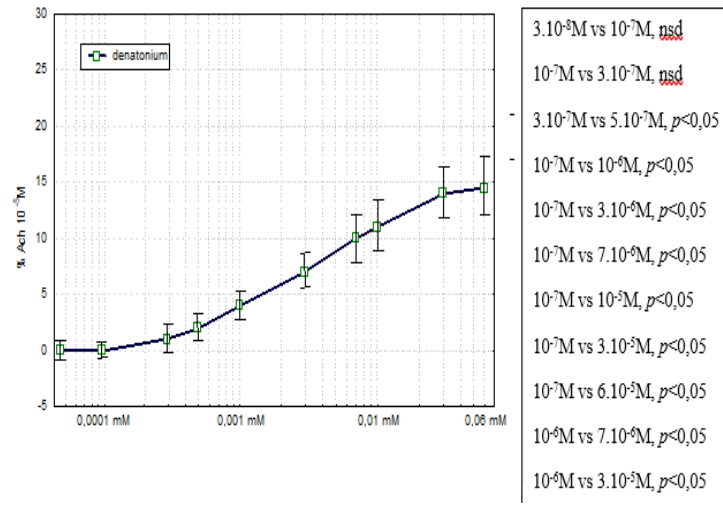

Figure 2: Left- Cumulative concentration-response curve of $3.10^{-8} \mathrm{M} \div 6.10^{-5} \mathrm{M}$ denatonium benzoate on the spontaneous contractility of smooth muscle strips isolated from rat gastric corpus. Results are presented as a percentage of the reaction of $10^{-5} \mathrm{M}$ acetylcholine. Each point is calculated as mean \pm SEM of seven preparations. Right- statistical analysis (Repeated Measures ANOVA and Bonferroni's Multiple Comparison Test); nsd- no statistically significant difference

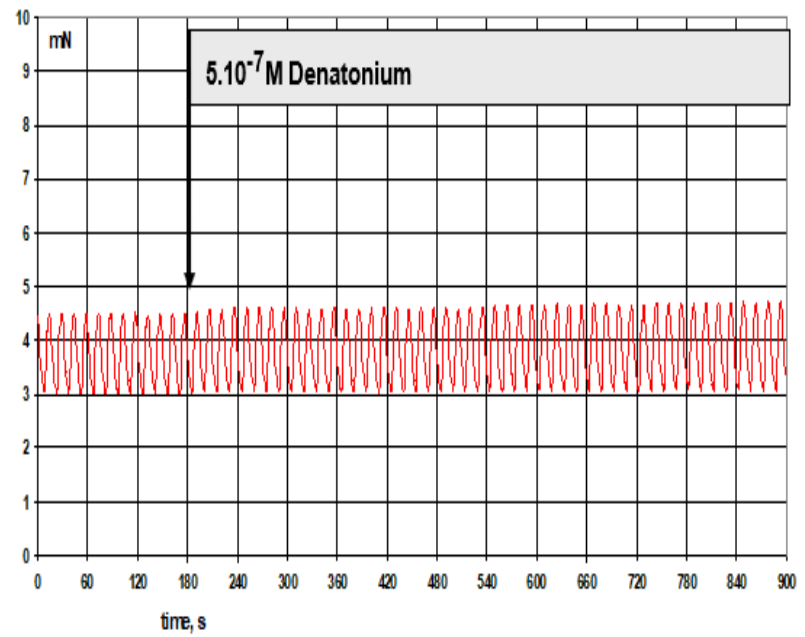

Figure 3: Change in the spontaneous contractility of smooth muscle strips isolated from rat gastric corpus under the influence of $5.10^{-7} \mathrm{M}$ denatonium $(n=7)$. Arrow indicates the initial point of denatonium benzoate-treatment

Trop J Pharm Res, September 2020; 19(9): 1882 

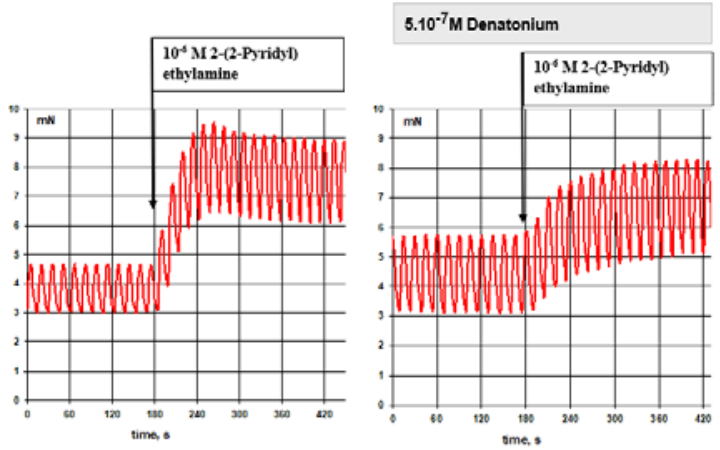

Figure 4: Change in the spontaneous contractility of smooth muscle strips isolated from rat gastric corpus under the influence of $10^{-6} \mathrm{M}$ 2-(2-Pyridyl) ethylamine $(n=7)$. 2-(2-Pyridyl) ethylamine $\left(10^{-6} \mathrm{M}\right)$ was added to the organ baths before (left) and after (right) $30 \mathrm{~min}$ of treatment of the strips with $5.10^{-7} \mathrm{M}$ denatonium. Arrows indicate the initial point of 2-(2-Pyridyl) ethylamine treatment

\section{DISCUSSION}

The results obtained from the histamine model of inflammation confirm the anti-inflammatory activity of DB which is demonstrated in several studies $[2,8,19]$. The mechanism of this effect is not fully understood.

DB is an agonist of TAS2Rs and some of these receptors (TAS2R4, TAS2R10 and TAS2R46) are found on the surface of mast cells. Other results showed significant inhibition of histamine and $\mathrm{PGD}_{2}$ release from lgE-receptor-activated primary human mast cells [19]. Orsmark et al detected the same subtypes in human leukocytes, including B and T-lymphocytes and suggested that DB could possess antiinflammatory and bronchodilator activity [8]. The presence of TAS2Rs in human lung macrophages and reduced LPS-induced cytokine production after DB- treatment has been reported [2].

During the process of acute inflammation, three phases could be distinguished and they are regulated by different mediators. The processes in the early phase (0 to $15 \mathrm{~min}$ ) are related to the release of histamine, serotonin, and bradykinin [20]. The study confirmed that histamine injection in the rat paw results in vasodilation and increased vascular permeability due to activation of the endothelial $\mathrm{H} 1$ receptors [21]. The results allow us to postulate that the effect of DB on the early stage of inflammation could be related to inhibition of synthesis, release or action of histamine. The vascular effects of histamine are mediated by endothelial $\mathrm{H} 1$ receptors and a possible explanation of the observed antiinflammatory effect of DB would be that the substance reduces the effect of histamine on the $\mathrm{H} 1$ receptors. To test this hypothesis, in vitro experiments to reveal the influence of $\mathrm{DB}$ on the histamine-H1 receptors were performed.

In the in vitro studies, the concentration of 0.5 $\mu \mathrm{M}$ was the lowest concentration of $\mathrm{DB}$ in which a statistically significant contractile effect was observed.

Avau et al report that the effect of DB on gastric smooth muscle contractility is concentration and region-dependent. Increasing concentrations of DB increases the contractility and the effect reaches its peak at $100 \mu \mathrm{M}$. Higher concentrations of DB (1 $\mathrm{mM})$ induce smooth muscle relaxation [6]. Concentrations, ranging from $1 \mu \mathrm{M}$ to $100 \mu \mathrm{M}$, evoke concentrationdependent contraction of smooth muscle strips isolated from gastric fundus and antrum of rodents. The results could be explained by the activation of TAS2Rs, given the abundant presence of different TAS2Rs subtypes in the fundus and the antrum $[6,22,23]$. Based on these results, we performed our experiments on smooth muscle strips isolated from the gastric corpus. We presumed that in this zone of the rat stomach the expression of TAS2Rs is poor. To avoid the influence of the substance on the bitter taste receptors and a cumulative contractile effect of TAS2Rs and $\mathrm{H} 1$ receptor activation, we performed the experiments using the concentration of $0.5 \mu \mathrm{M} \mathrm{DB}$. This is the lowest concentration of $D B$ which induces the minimal statistically significant contractile effect. Thus, the strong contractile effect of TAS2Rs observed at higher concentrations of DB is avoided and this allows us to study the effect of DB on other receptor type.

Figure 3 demonstrates the efficiency of the selected model used in the study, allowing the calculation of DB concentration $(0.5 \mu \mathrm{M})$, which induces acceptable contractile effect.

The observed effects after treatment with DB and $\mathrm{H} 1$ agonist are unlikely to be related to bitter taste receptors activation and the changes in the contractility are dominated by histamine receptors. Thus, after the addition of $\mathrm{H} 1$ agonist, we could study the effect of DB on histamine receptors.

The smooth muscle response to $\mathrm{H} 1$ receptor agonist was reduced in the presence of DB (Fig.4). The result allows us to postulate a possible effect of DB on the histamine receptors. This hypothesis could also explain the observed anti-inflammatory effect of DB during the early stage of histamine-induced rat paw edema. The 
vascular effects of histamine are mediated by endothelial histamine- $\mathrm{H} 1$ receptors [21] and substances, which block these receptors, could influence the early phase of histamine-induced inflammation.

\section{CONCLUSION}

Intraperitoneal injection of denatonium benzoate (DB) attenuates the initial phase of histamineinduced paw inflammation in rats, and also decreases the response of smooth muscle strips to histamine- $\mathrm{H} 1$ receptor agonist. The reduced effect of histamine on histamine- $\mathrm{H} 1$ receptors likely contributes to the anti-inflammatory activity of DB in rat paw edema. The results constitute a strong basis for the search for new antiinflammatory drugs.

\section{DECLARATIONS}

\section{Acknowledgement}

This work was funded by National Programme "Junior Scientists and Postdocs - second stage" and partially by Bulgarian National Research Fund(nos. KP06-N31/15 and DN11/15), and NATO (no. SPS MYP G526).

\section{Conflict of interest}

No conflict of interest is associated with this research.

\section{Contribution of authors}

The authors declare that this work was done by the authors named in this article and all liabilities pertaining to claims relating to the content of this article will be borne by them. Plamen Zagorchev conceived and designed the study, collected and analyzed the data, and supervised the study. Vesela Kokova participated in the study design, the data collection, the statistical analysis and the writing of the manuscript. Elisaveta Apostolova participated in the design of the study, collected and analyzed the data, performed the statistical analysis and wrote the manuscript. Milena Draganova-Filipova participated in the writing of the manuscript. All authors read the article and approved the final version of the manuscript.

\section{Open Access}

This is an Open Access article that uses a funding model which does not charge readers or their institutions for access and distributed under the terms of the Creative Commons Attribution License (http://creativecommons.org/licenses/by/ 4.0) and the Budapest Open Access Initiative (http://www.budapestopenaccessinitiative.org/rea d), which permit unrestricted use, distribution, and reproduction in any medium, provided the original work is properly credited.

\section{REFERENCES}

1. Meyerhof W, Batram C, Kuhn C, Brockhoff A, Chudoba E, Bufe B, Appendino G, Behrens M. The Molecular Receptive Ranges of Human TAS2R Bitter Taste Receptors. Chemical Senses 2010; 35(2): 157-170.

2. Grassin-Delyle S, Salvator H, Mantov N, Abrial C, Brollo M, Faisy C, Naline E, Couderc L-J, Devillier P. Bitter Taste Receptors (TAS2Rs) in Human Lung Macrophages: Receptor Expression and Inhibitory Effects of TAS2R Agonists. Front Physiol 2019; 10: 1267.

3. Lu P, Zhang $\mathrm{CH}$, Lifshitz LM, ZhuGe R. Extraoral bitter taste receptors in health and disease. J Gen Physiol 2017; 149(2): 181-197.

4. Campa D, De Rango F, Carrai M, Crocco P, Montesanto A, Canzian F, Rose G, Rizzato C, Passarino G, Barale $R$. Bitter taste receptor polymorphisms and human aging. PLoS One 2012; 7(11): e45232.

5. Luo M, Ni K, Jin Y, Yu Z, Deng L. Toward the Identification of Extra-Oral TAS2R Agonists as Drug Agents for Muscle Relaxation Therapies via Bioinformatics-Aided Screening of Bitter Compounds in Traditional Chinese Medicine. Front Physiol 2019; 10: 861.

6. Avau B, Rotondo A, Thijs T, Andrews C, Janssen P, Tack J, Depoortere I. Targeting extra-oral bitter taste receptors modulates gastrointestinal motility with effects on satiation. Sci Rep 2015; 5: 15985.

7. Zagorchev P, Petkov GV, Gagov HS. Bitter Taste Receptors as Regulators of Abdominal Muscles Contraction. Physiol Res 2019; 68(6): 991-995.

8. Orsmark-Pietras $C$, James A, Konradsen JR, Nordlund B, Söderhäll C, Pulkkinen V, Pedroletti C, Daham K, Kupczyk M, Dahlén B, et al. Transcriptome analysis reveals upregulation of bitter taste receptors in severe asthmatics. Eur Respir J 2013; 42(1): 65-78.

9. Malki A, Fiedler J, Fricke K, Ballweg I, Pfaffl MW, Krautwurst $D$. Class I odorant receptors, TAS1R and TAS2R taste receptors, are markers for subpopulations of circulating leukocytes. J Leukoc Biol 2015; 97: 533545.

10. Jutel $M$, Akdis $M$, Akdis CA. Histamine, histamine receptors and their role in immune pathology. Clinical \& Experimental Allergy 2009; 39: 1786-1800.

11. Thangam $E B$, Jemima $E A$, Singh $H$, Baig MS, Khan $M$, Mathias CB, Church MK, Saluja R. The Role of Histamine and Histamine Receptors in Mast CellMediated Allergy and Inflammation: The Hunt for New Therapeutic Targets. Front Immunol 2018; 9: 1873.

Trop J Pharm Res, September 2020; 19(9): 1884 
12. Branco ACCC, Yoshikawa FSY, Pietrobon AJ, Sato MN. Role of Histamine in Modulating the Immune Response and Inflammation. Mediators Inflamm 2018: 9524075.

13. International Council for Ethical Guidelines for Animal Breeding Labs for Researchers, ARRIVE. Available from: https://www.etikkom.no/en/ethical-guidelines-forresearch/ethical-guidelines-for-the-use-of-animals-inresearch/

14. EU Directive 2010/63/EU for animal experiments. Available from: https://eur-lex.europa.eu/LexUriServ/ LexUriServ.do?uri=OJ:L:2010:276:0033:0079:en:PDF

15. Nakamura $H$, Shimizu M. Early and delayed phases of hind paw edema in rats. Jpn J Pharmacol 1974; 24(3): 393-405.

16. Andonova V, Peneva P, Georgiev GS, Toncheva VT, Apostolova E, Peychev Z, Dimitrova S, Katsarova M, Petrova N, Kassarova M. Ketoprofen-loaded polymer carriers in bigel formulation: an approach to enhancing drug photostability in topical application forms. Int $J$ Nanomedicine 2017; 12: 6221-6238.

17. Zagorchev P, Apostolova E, Kokova V, Peychev L. Activation of KCNQ channels located on the skeletal muscle membrane by retigabine and its influence on the maximal muscle force in rat muscle strips. Naunyn Schmiedeberg's Arch Pharmacol 2016; 389(4): 439-446.

18. Zagorchev P, Apostolova E, Kokova V, Peychev L, Peychev Z, Draganova-Filipova M. Activation of Kv7.2 to
Kv7.5 channels by retigabine modulates the effects of histamine and 2-(2-Pyridyl) ethylamine on smooth muscles. Comptes rendus de l'Acade'mie bulgare des Sciences 2018; 71(10): 1428-1436.

19. Ekoff M, Choi JH, James A, Dahlen B, Nilsson G, Dahlen $S E$. Bitter taste receptor (TAS2R) agonists inhibit lgEdependent mast cell activation. J Allergy Clin Immunol 2014; 134(2): 475-478.

20. Sowemimo A, Onakoya M, Fageyinbo MS, Fadoju $T$. Studies on the anti-inflammatory and anti-nociceptive properties of Blepharis maderaspatensis leaves. Revista Brasileira de Farmacognosia 2013; 23(5): 830-835.

21. Kalokasidis K, Molyva D, Mirtsou V, Kokkas B, Goulas A. Evidence for the contribution of tumour necrosis factor in oedema formation induced by histamine in the hind paw of the rat. Inflamm Res 2009; 58(8): 437-440.

22. Wu SV, Rozengurt N, Yang M, Young SH, Sinnett-Smith $J$, Rozengurt E. Expression of bitter taste receptors of the $T 2 R$ family in the gastrointestinal tract and enteroendocrine STC-1 cells. Proc Natl Acad Sci U S A 2002; 99(4): 2392-2397.

23. Wu SV, Chen MC, Rozengurt E. Genomic organization, expression, and function of bitter taste receptors (T2R) in mouse and rat. Physiol Genomics 2005; 22(2): 139149. 